\title{
Penerapan Kegiatan Bimbingan Berkelanjutan Untuk Meningkatkan Kemampuan Guru Budang Study Dalam Menyusun Perangkat Pembelajaran di SMP Negeri 3 Pasie Raya Tahun Pelajaran 2019/2020
}

\author{
Raudhatul Hayati, S.Ag \\ SMP Negeri Pasie Raya
}

\begin{abstract}
Abstrak
Perangkat Pembelajaran Seperti Silabus, RPP, Media Pembelajaran, Bahan Ajar, dan lai sebagainya merupakan salah satu pokok administras guru dari beberapa komponen lainnya dalam proses pembelajaran. Kelemahan dalam menyusun perangkat tersebut sering terjadi pada saat sebelum proses pelaksanaan pembelajaran, dengan demikian dalam menyusun dan merancang perangkat tersebut diharapkan benar-benar efesien dan bermakna. Setelah melakukan supervisi perlu dilakukan perubahan oleh setiap guru dalam menyusun perangkat pembelajaran yang sesuai dengan materi yang diajarkan. PTS ini dilakukan dalam 2 (dua) siklus. Penelitian ini dilaksanakan pada bulan November s.d Desember 2019 di SMP Negeri 3 Pasie Raya yang berjumlah 3 orang guru bidang Study yang terdiri dari 1 Guru PJOK, 1 guru Matematika, dan 1 guru Bahasa Inggris. Untuk pengumpulan data peneliti menggunakan bimbingan berkelanjutan yang berkelanjutan. Pengolahan data dilakukan dengan wawancara, pengamatan, dan observasi terhadap penyusunan perangkat pembelajaran oleh setiap guru bidang study. Berdasarkan penelitian ada peningkatan kemampuan guru dalam menyusun perangkat pembelajaran yang efektif sehingga proses pembelajaran lebih bermakna dan bermutu seperti yang diharapkan.
\end{abstract}

Kata kunci : Bimbingan, Berkelanjutan, Guru, perangkat pembelajaran

\section{PENDAHULUAN}

Guru adalah pahlawan tanpa tanda jasa yang tugasnya sangat mulia dalam membina, mendidik, membimbing dan melatih sejumlah manusia secara teratur dan kontiniu. Sebagaimana kita ketahui bahwa berhasilnya anak didik adalah karena pandainya guru dalam mengajar, kepribadian guru sangat menentukan dalam pendidikan, apakah ia menjadi pendidik dan pembina yang baik ataukah menjadi perusak dan penghancur masa depan anak didik .

Guru professional akan tercermin dalam penampilan pelaksanaan pengabdian tugas-tugas yang ditandai dengan keahlian baik dalam materi maupun metode. Keahlian yang dimiliki oleh guru profesional adalah keahlian yang diperoleh melalui suatu proses pendidikan dan pelatihan yang diprogramkan secara khusus untuk itu. Keahlian tersebut mendapat pengakuan formal yang dinyatakan dalam bentuk sertifikasi, akreditasi, dan lisensi dari pihak yang berwenang (dalam hal ini pemerintah dan organisasi profesi). Dengan keahliannya itu seorang guru mampu menunjukkan otonominya, baik secara pribadi maupun sebagai pemangku profesinya.

Terkait dengan kemampuan guru, dalam penelitian ini akan memperdalam pembahsan tentang kemampuan guru bidang study dalam menyusun Perangkat Pembelajaran . Pentingnya kemampuan tersebut adalah untuk menunjang keberhasilan pembelajaran. 
Perencanaan pembelajaran merupakan langkah yang sangat penting sebelum pelaksanaan pembelajaran. Perencanaan yang matang diperlukan supaya pelaksanaan pembelajaran berjalan secara efektif. Perencanaan pembelajaran dituangkan ke dalam perangkat pembelajaran atau beberapa istilah lain seperti desain pembelajaran, skenario pembelajaran dan lain sebagainya. Perangkat Pembelajaran memuat tingkat pencapaian perkembangan, indikator yang akan dicapai, materi yang akan dipelajari, metode pembelajaran, langkah pembelajaran, media pembelajaran, dan sumber belajar serta penilaian.

Perangkat pembelajaran dikembangkan oleh guru pada satuan pendidikan . Guru pada satuan pendidikan berkewajiban menyusun silabus, Perangkat Pembelajaran secara lengkap dan sistematis agar pembelajaran berlangsung secara interaktif, inspiratif, menyenangkan, menantang, memotivasi peserta didik untuk berpartisipasi aktif, serta memberikan ruang yang cukup bagi prakarsa, kreativitas, dan kemandirian sesuai dengan bakat, minat dan perkembangan fisik serta psikologis peserta didik.

Pada komponen penilaian (penskoran) sebagian besar guru tidak lengkap membuatnya dengan alasan sudah tahu dan ada di kepala. Sedangkan pada komponen tujuan pembelajaran, materi ajar, metode pembelajaran, dan sumber belajar sebagian besar guru sudah membuatnya.

Rencana Pelaksanaan Pembelajaran harus dibuat agar kegiatan pembelajaran berjalan sistematis dan mencapai tujuan pembelajaran. Tanpa Rencana Program Pembelajaran, biasanya pembelajaran menjadi tidak terarah. Oleh karena itu, guru harus mampu menyusun Perangkat Pembelajaran dengan lengkap berdasarkan silabus yang disusunnya. Rencana Program Pembelajaran sangat penting bagi seorang guru karena merupakan acuan dalam melaksanakan proses pembelajaran.

Berdasarkan uraian latar belakang di atas maka penulis tertarik untuk mengadakan penelitian yang akan dituangkan dalam sebuah bentuk tulisan laporan penelitian tindakan sekolah dengan judul "Penerapan Kegiatan Bimbingan Berkelanjutan dalam Meningkatkan Kemampuan Guru Bidang Study dalam Menyusun Perangkat Pembelajaran Di SMP Negeri 3 Pasie Raya Kecamatan Pasie Raya Kabupaten Aceh Jaya Tahun Pelajaran 2019/2020".

\section{Tujuan Penelitian}

Tujuan dari penelitian ini adalah untuk mengetahui Implementasi bimbingan berkelanjutan untuk meningkatkan kemampuan guru dalam menyusun Perangkat Pembelajaran di SMP Negeri 3 Pasie Raya Kecamatan Pasie Raya Kabupaten Aceh Jaya.

\section{KAJIAN PUSTAKA Pengertian Guru}

UU Guru dan Dosen Republik Indonesia No.14 Tahun 2005 "Guru adalah pendidik profesional dengan tugas utama mendidik, mengajar, membimbing, mengarahkan, melatih, menilai, dan mengevaluasi peserta didik pada pendidikan anak usia dini jalur pendidikan formal, pendidikan dasar, dan pendidikan menengah".

Selanjutnya UU No.20 Tahun 2003 pasal 39 ayat 2 tentang sistem pendidikan nasional menyatakan, "pendidik merupakan tenaga profesional yang bertugas merencanakan dan melaksanakan proses pembelajaran, menilai hasil pembelajaran, melakukan pembimbingan dan pelatihan, serta melakukan penelitian dan pengabdian kepada masyarakat, terutama bagi pendidik pada perguruan tinggi." PP No.19 Tahun 
2005 tentang Standar Nasional Pendidikan menyatakan, "pendidik (guru) harus memiliki kualifikasi akademik dan kompetensi sebagai agen pembelajaran, sehat jasmani dan rohani, serta memiliki kemampuan untuk mewujudkan tujuan pendidikan nasional."

Berdasarkan definisi di atas, dapat disimpulkan bahwa guru adalah tenaga pendidik yang profesional dengan tugas utama mendidik, mengajar, membimbing, mengarahkan, melatih, menilai dan mengevaluasi peserta didik, dan bertugas merencanakan dan melaksanakan proses pembelajaran.

\section{Perangkat Pembelajaran}

Perencanaan proses pembelajaran meliputi silabus Perangkat Pembelajaran . Silabus merupakan sebagian sub-sistem pembelajaran yang terdiri dari atau yang satu sama yang lain saling berhubungan dalam rangka mencapai tujuan. Hal penting yang berkaitan dengan pembelajaran adalah penjabaran tujuan yang disusun berdasarkan

Philip Combs (dalam Kurniawati, 2009:66) menyatakan bahwa perencanaan program pembelajaran merupakan suatu penetapan yang memuat komponen-komponen pembelajaran secara sistematis. Analisis sistematis merupakan proses perkembangan pendidikan yang akan mencapai tujuan pendidikan agar lebih efektif dan efisien disusun secara logis, rasional, sesuai dengan kebutuhan siswa, sekolah, dan daerah (masyarakat). Perencanaan program pembelajaran adalah hasil pemikiran, berupa keputusan yang akan dilaksanakan.

Selanjutnya Oemar Hakim (dalam Kurniawati 2009:74) menyatakan, "bahwa perencanaan program pembelajaran pada hakekatnya merupakan perencanaan program jangka pendek untuk memperkirakan suatu proyeksi tentang sesuatu yang akan dilakukan dalam kegiatan pembelajaran".

\section{Bimbingan Berkelanjutan}

Frank Parson. 1951 (dalam RM Fatihah http://eko13.wordpress.com) menyatakan, "bimbingan sebagai bantuan yang diberikan kepada individu untuk dapat memilih, mempersiapkan diri dan memangku suatu jabatan dan mendapat kemajuan dalam jabatan yang dipilihnya." Chiskon 1959 (dalam RM Fatihah http://eko13.wordpress.com) menyatakan, "bimbingan membantu individu untuk lebih mengenal berbagai informasi tentang dirinya sendiri."

Berdasarkan pengertian bimbingan dan berkelanjutan dapat ditarik suatu kesimpulan bahwa bimbingan berkelanjutan adalah pemberian bantuan yang diberikan seorang ahli kepada seseorang atau individu secara berkelanjutan berlangsung secara terus menerus untuk dapat mengembangkan potensi dirinya secara optimal dan mendapat kemajuan dalam bekerja.

\section{METODOLOGI PENELITIAN Subjek Penelitian}

Subyek dalam PTS ini adalah guru bidang study di SMP Negeri 3 Pasie Raya Kecamatan Pasie Raya Kabupaten Aceh Jaya. Berikut ini adalah nama nama subjek penelitian :

Tabel Subjek Penelitian

\begin{tabular}{|c|l|c|}
\hline No. & \multicolumn{1}{|c|}{ Nama Guru } & Bid.Study yg diampu \\
\hline 1 & Meutia Hanum, S.Pd & Bahasa Inggris \\
\hline 2 & Suriadi, S.Pd.I & Matematika \\
\hline
\end{tabular}




\begin{tabular}{|l|l|l|}
\hline 3 & T. Hasan. S.Pd.,M.Pd & Penjaskes \\
\hline
\end{tabular}

\section{Tempat dan Waktu Penelitian}

Penelitian Tindakan Sekolah ini di adakan di SMP Negeri 3 Pasie Raya Kecamatan Pasie Raya Kabupaten Aceh Jaya. Pemilihan tempat ini karena banyak guru bidang study di SMP Negeri 3 Pasie Raya tersebut yang perlu di tingkatkan kemampuannya dalam menyusun Perangkat Pembelajaran. Berikut ini adalah keadaan siswa di SMP Negeri 3 Pasie Raya Kecamatan Pasie Raya Kabupaten Aceh Jaya. PTS ini dilaksanakan pada semester genap tahun pelajaran 2019-2020 mulai 25 November s.d 15 Desember 2019.

\section{Prosedur Penelitian}

Prosedur penelitian adalah suatu rangkaian tahap-tahap penelitian dari awal sampai akhir. Penelitian ini merupakan proses pengkajian sistem berdaur sebagaimana kerangka berpikir yang dikembangkan oleh Suharsimi Arikunto dkk. Prosedur ini mencakup tahap-tahap perencanaan, pelaksanaan, pengamatan, dan refleksi.

\section{Alat Pengumpulan Data} dan diskusi.

Teknik pengumpulan data dalam penelitian ini adalah wawancara, observasi,

\section{Tekhnik Analisa Data}

Langkah-langkah yang perlu dilakukan dalam analisis data seperti ini yaitu memilih data (reduksi data), mendeskripsikan data hasil temuan (memaparkan data), menarik kesimpulan hasil deskripsi.

\section{HASIL PENELITIAN DAN PEMBAHASAN Hasil Observasi pada Siklus I}

Proses Pembelajaran yang dilakukan pada guru bidang study Penjaskes mulai dari kelas VII s.d IX di SMP Negeri 3 Pasie Raya Kecamatan Pasie Raya Kabupaten Aceh Jaya tentunya dilengkapi dengan semua perangkat pembelajaran, sebelum dilakukan penelitian semua dianjurkan membuat semua perangakat pembelajarannya.

Berdasarkan pengamatan terhadap observasi guru bidang study Bahasa Inggris (Sdri. Meutia Hanum, S.Pd), Matematika (Sdra. Suriadi, S.Pd.I), dan Penjaskes (Sdra. T. Hasan, S.Pd.,M.Pd) pada kelas VII s.d IX, setelah dilaksanakan penelitian menunjukkan bahwa masih rendahnya kemampuan guru dalam membuat perangkat pembelajaran. Hal ini dapat dibuktikan pada tabel di bawah ini :

Tabel Nilai Observasi Guru Dalam Membuat Perangkat Pembelajaran Tahap Siklus I

\begin{tabular}{|c|c|c|c|c|c|c|}
\hline No & Mapel & VII & VIII & IX & Rata-rata & Katagori \\
\hline 1 & Bhs. Inggris & 65 & 60 & 65 & 64 & Kurang \\
\hline 2 & Matematika & 70 & 65 & 60 & 67 & Kurang \\
\hline 3 & Penjaskes & 60 & 60 & 65 & 64 & Kurang \\
\hline \multicolumn{2}{|c|}{ Jumlah } & $\mathbf{6 5}$ & $\mathbf{6 2}$ & $\mathbf{6 3}$ & $\mathbf{6 5}$ & Kurang \\
\hline
\end{tabular}

Tabel diatas menunjukkan bahwa penilai guru dalam membuat perangkat masih dalam katagori kurang, dimana nilai rata-rata dari guru Bahasa Inggris hanya mendapat nilai 65, guru Matematika 62, dan guru Penjaskes hanya 63. Hal ini menunjukkan 
bahwa kemampuan guru dalam membuat perangkat perlu ada perbaikan dan bimbingan pada siklus selanjutnya.

\section{Deskripsi Hasil Penelitian \\ Siklus I}

Siklus I dilaksanakan pada tanggal 25 September 2019 s.d 30 September 2019 dengan jumlah guru mapel yaitu Bahasa Inggris, Matematika, dan Penjaskes. Siklus I dilaksanakan dalam empat tahap, tahapan-tahapan tersebut antara lain :

a. Perencanaan

Langkah pertama yang dilakukan sebelum melaksanakan penelitian adalah mempersiapkan format wawancara kesediaan Rencana Pelaksanaan Pembelajaran (RPP) guru.

b. Pelaksanaan

Peneliti memberikan bimbingan dalam merancang dan meyusun perangkat pembelaran yang baik.

c. Pengamatan/Obeservasi

Peneliti melakukan pengamatan terhadap perangkat pembelajaran yang telah dibuat untuk memotret seberapa jauh kemampuan guru dalam menyusun perangkat pembelajaran dengan lengkap, hasil atau dampak dari tindakan yang telah dilaksanakan oleh guru dalam mencapai sasaran. Hasil rekapitulasi data tersebut dapat dilihat sebagai berikut :

Tabel Rekapitulasi Lembar Pengamatan Penyusunan Perangkat Pembelajaran Siklus I

\begin{tabular}{|c|l|c|c|c|c|c|}
\hline No & \multicolumn{1}{|c|}{ Aspek yang dinilai } & $\begin{array}{c}\text { B. } \\
\text { Ing }\end{array}$ & MTK & Penjas & $\begin{array}{c}\text { Rata- } \\
\text { rata }\end{array}$ & $\begin{array}{c}\text { Perentase } \\
(\%)\end{array}$ \\
\hline 1 & $\begin{array}{l}\text { Kemampuan } \\
\text { mengembangkan indikator }\end{array}$ & 4 & 3 & 3 & 3 & $60 \%$ \\
\hline 2 & $\begin{array}{l}\text { Kemampuan merumuskan } \\
\text { tujuan pembelajaran }\end{array}$ & 4 & 4 & 4 & 4 & $65 \%$ \\
\hline 3 & $\begin{array}{l}\text { Kemampuan dalam } \\
\text { menentukan materi/bahan } \\
\text { ajar }\end{array}$ & 3 & 4 & 3 & 3 & $60 \%$ \\
\hline 4 & $\begin{array}{l}\text { Kemampuan dalam } \\
\text { menentukan sumber } \\
\text { belajar }\end{array}$ & 3 & 3 & 3 & 3 & $60 \%$ \\
\hline 5 & $\begin{array}{l}\text { Kemampuan menetukan } \\
\text { metode pembelajaran }\end{array}$ & 3 & 3 & 4 & 3 & $60 \%$ \\
\hline 6 & $\begin{array}{l}\text { Kemampuan menetunkan } \\
\text { media pembelajaran }\end{array}$ & 4 & 2 & 3 & 3 & $60 \%$ \\
\hline 7 & $\begin{array}{l}\text { Kemampuan menetukan } \\
\text { penilaian }\end{array}$ & 3 & 3 & 3 & 3 & $60 \%$ \\
\hline
\end{tabular}

Rekapitulasi data pengamatan guru di atas dapat diketahui bahwa pengamatan terhadap persentase kemampuan guru dalam menyusun perangkat pembelajaran hanya $60 \%$.

d. Refleksi Siklus I

Berdasarkan hasil pengamatan Peneliti mengkaji, melihat, dan mempertimbangkan hasil atau dampak dari tindakan yang telah dilakukan. Berdasarkan hasil dari refleksi ini, peneliti bersama guru melaksanakan revisi atau perbaikan terhadap perangkat 
pembelajaran yang telah disusun agar sesuai dengan rencana awal yang mungkin saja masih bisa sesuai dengan yang peneliti inginkan.

\section{Siklus II}

Hasil penelitian pada siklus I belum memuaskan dan belum mencapai indikator keberhasilan yang ditentukan peneliti, maka dilanjutkan ke siklus II yang dilaksanakan pada tanggal 05 s.d 10 Desember 2019, dengan jumlah guru yang sama yaitu guru Bahasa Inggris, Matematika, dan Penjaskes.

Tahapan-tahapan pada siklus II sama dengan tahapan yang dilakukan pada siklus I, Cuma pada siklus II ini adalah : menyelidiki kembali hasil perbaikan guru dalam menyusun semua perangkat pembelajaran. Hasil rekapitulasi data tersebut dapat dilihat sebagai berikut :

Tabel Rekapitulasi Lembar Pengamatan Penyusunan

Perangkat Pembelajaran Siklus II

\begin{tabular}{|c|l|c|c|c|c|c|}
\hline No & \multicolumn{1}{|c|}{ Aspek yang dinilai } & B.Ing & MTK & Penjas & $\begin{array}{c}\text { Rata- } \\
\text { rata }\end{array}$ & $\begin{array}{c}\text { Perentase } \\
(\%)\end{array}$ \\
\hline 1 & $\begin{array}{l}\text { Kemampuan } \\
\text { mengembangkan indikator }\end{array}$ & 4 & 4 & 4 & 4 & $100 \%$ \\
\hline 2 & $\begin{array}{l}\text { Kemampuan merumuskan } \\
\text { tujuan pembelajaran }\end{array}$ & 4 & 4 & 4 & 4 & $100 \%$ \\
\hline 3 & $\begin{array}{l}\text { Kemampuan dalam } \\
\text { menentukan materi/bahan } \\
\text { ajar }\end{array}$ & 4 & 4 & 4 & 4 & $100 \%$ \\
\hline 4 & $\begin{array}{l}\text { Kemampuan dalam } \\
\text { menentukan sumber belajar }\end{array}$ & 4 & 4 & 4 & 4 & $100 \%$ \\
\hline 5 & $\begin{array}{l}\text { Kemampuan menetukan } \\
\text { metode pembelajaran }\end{array}$ & 4 & 4 & 4 & 4 & $100 \%$ \\
\hline 6 & $\begin{array}{l}\text { Kemampuan menetunkan } \\
\text { media pembelajaran }\end{array}$ & 4 & 4 & 4 & 4 & $100 \%$ \\
\hline 7 & $\begin{array}{l}\text { Kemampuan menetukan } \\
\text { penilaian }\end{array}$ & 4 & 4 & 4 & 4 & $100 \%$ \\
\hline
\end{tabular}

Rekapitulasi data pengamatan guru di atas dapat diketahui bahwa pengamatan terhadap kemampuan guru dalam menyusun perangkat pada siklus II diperoleh skor persentase $100 \%$ pada kategori baik.

\section{Pembahasan}

Dengan kerjasama antara peneliti dengan dewan guru dalam melakukan bimbingan terhadap menyusun perangkat pembelajaran akan menghasilkan hasil yang baik. Hasil kemampuan guru dalam menyusun perangkat pembelajaran meningkat dari setiap siklusnya. Pada siklus I hasil kemampuan guru masih dibawah rata-rata hanya sebesar $60 \%$ sementara pada sikus II dapat diketahui bahwa terjadi peningkatan jumlah persentase yang mencapai $100 \%$. 
Target ketuntasan tersebut dapat digambarkan dalam diagram di bawah ini :

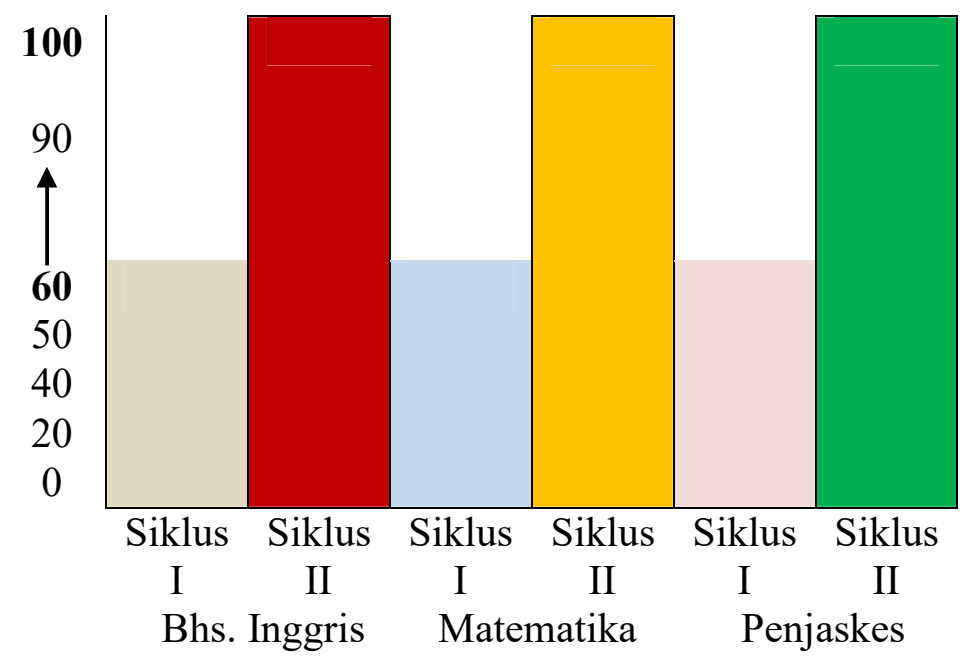

Gambar Persentase siklus I dan siklus II

Persentase ketuntasan yang diperoleh pada setiap siklusnya juga mengalami peningkatan. Kriteria ketuntasan klasikal yang digunakan peneliti adalah apabila persentase ketuntasan klasikal mencapai maka penelitian dapat dikatakan berhasil.

Kriteria ketuntasan dinyatakan dengan nilai 4 (100\%), sementara pada siklus I hanya mendapat reratanya $3(60 \%)$ dan pada siklus II persentase meningkat menjadi $(100 \%)$ karena sudah mendapat nilai 4.

\section{Kesimpulan}

Berdasarkan hasil penelitian yang dilakukan di SMP Negeri 3 Pasie Raya Kecamatan Pasie Raya Kabupaten Aceh Jaya, dapat disimpulkan yaitu meningkatkan kemampuan guru dalam menyusun perangkat pembelajaran dengan diadakan pengamatan terhadap perangkat pembelajaran guru. Kemampuan guru dalam menyusun Rencana Pelaksanaan Pembelajaran (RPP) dapat dicermati melalui kemampuannya dalam merancang setiap komponen pembelajaran secara terpadu. Komponen pembelajaran yang dimaksud meliputi: pengembangan indikator; penentuan tujuan pembelajaran; penentuan materi/bahan ajar; penentuan sumber belajar; penentuan metode pembelajaran; penentuan media pembelajaran; dan penilaian, hal ini perlu di asah terus-menurus sehingga proses pembelajaran yang dilakukan guru agar menciptakan pembaharuan menuju kearah pendidikan yang maju dan bermutu.

\section{DAFTAR PUSTAKA}

Dewi, Kurniawati Eni . 2009. Pengembangan Bahan Ajar Bahasa Dan Sastra Indonesia Dengan Pendekatan Tematis. Tesis. Surakarta: Program Pascasarjana Universitas Sebelas Maret.

Depdiknas. 2003. UU RI No. 20 Tahun 2003 tentang Sistem Pendidikan Nasional. Jakarta: Depdiknas. 2005. UU RI No. 14 Tahun 2005 tentang Guru dan Dosen. Jakarta: Depdiknas. 2005. Standar Nasional Pendidikan. Jakarta: Depdiknas.

Fatihah, RM . 2008. Pengertian konseling (Http://eko13.wordpress.com, diakses 19 Maret 2009). 